\title{
A Relational Analysis of Teachers' Approaches to Curriculum Design and Classroom Management Styles
}

\author{
Dr. Alper Aytaç (Teacher) \\ Ministry of National Education-Turkey \\ ORCID: 0000-0002-5087-8482 \\ alperaytac10@gmail.com
}

\author{
Necip Kaygısız (Teacher) \\ Ministry of National Education-Turkey \\ ORCID: 0000-0002-5614-7269 \\ necipbey.org@gmail.com
}

\begin{abstract}
:
The aim of this study is to examine the relationship between teachers' approaches to curriculum design and classroom management styles. The sample of the study, which was designed using a correlational survey model, consisted of 334 teachers working in various schools in Turkey during the 2020 - 2021 academic year. The sampling method employed was convenient sampling. The Approaches to Curriculum Design Scale and the Classroom Management Styles Scale were used as data collection tools. Descriptive statistics (arithmetic mean \& standard deviation), Pearson's correlation coefficients, and multivariate regression analysis were used to analyze the data set. Analysis of the results of the study's first question revealed that teachers, to a large degree, prefer learner-centered curriculum designs as well as the authoritative classroom management style. Within the purview of the second question of the study, significant relationships between teachers' approaches to curriculum design and classroom management styles were examined. Analysis of the results of the study's third question showed that teachers' approaches to curriculum design significantly predicted classroom management styles. Consequently, teachers' approaches to curriculum design were found to account for $17 \%$ of the variance of the authoritarian classroom management sub-dimension, 5\% of the variance of the uninvolved classroom management sub-dimension, $25 \%$ of the variance of the authoritative classroom management sub-dimension, and $9 \%$ of the variance of the permissive classroom management sub-dimension. Keeping this in mind, various in-service training programs regarding the importance of approaches to curriculum design during the teaching and learning process can be organized. In addition, in another study to be conducted, more detailed results can be obtained by using the mixed method with a larger sample size.
\end{abstract}

Keywords: Curriculum, Approaches to curriculum design, Classroom management, Classroom management styles, Teachers.

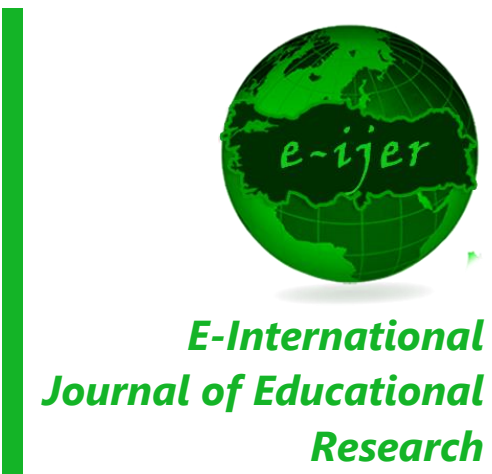

Vol: 12, No: 4, pp. $20-40$

Research Article
Received : 2021-04-26 Accepted : 2021-09-30

\section{Suggested Citation}

Aytaç, A. ve Kaygısız, N. (2021). A relational analysis of teachers' approaches to curriculum design and classroom management styles. E-International Journal of Educational Research, 12(4), 20-40. DOI: https://doi.org/10.19160/e-ijer.928384 


\section{INTRODUCTION}

Curriculum refers to many types of planned teaching and learning activities. Learning environments are created for students through activities organized either inside or out of school (Demirel, 2007). It is essential to reach certain pre-defined objectives when creating these environments (Tyler, 2014); preparing curriculum content, identifying relevant learning strategies, and properly utilizing assessment and evaluation criteria are crucial steps in the process of accomplishing these objectives (Fidan, 2012; Varış, 1978). These objectives can also be achieved with proper curriculum development (Print, 1993). Planning, on the other hand, refers to the process of developing the curriculum (Oliva, 1997). Thus, it can be said that curriculum design is essentially a plan that indicates which elements the curriculum is made up of and how these elements need to be grouped and organized (Saylan, 1995). Specific philosophical approaches underly every type of curriculum design (Korkmaz, 2017). There are three principal approaches to curriculum design: "subject-centered design" "learner-centered design" and "problem-centered design" (Alcl, 2014, p. 72).

Subject-centered design is an approach that is based on teaching certain academic disciplines; it can be said that curriculum content and the transfer of information constitute the basis for this approach (Print, 1993; Tanner \& Tanner, 1995). Subject-centered designs, which are the oldest and most common approach, typically form around the gradual accretion of knowledge in particular fields of study and academic disciplines (Büyükkaragöz, 1997; Korkmaz, 2017). As such, it can be stated that coursebooks play a key role in this approach (Ornstein \& Hunkins, 2014). As for the philosophical framework of this design, subject-centered design can be said to be under the influence of idealism (Sönmez, 2001). Thus, subject-centered designs are typically associated with traditional movements in educational philosophy (Kozikoğlu \& Uygun, 2018). Another approach to curriculum design is learner-centered design, which, contrary to subjectcentered design, is based on planning a curriculum by taking students' needs and interests into account rather than focusing on the subject itself or academic disciplines. In addition, learnercentered designs are considered to be more suitable for primary education (Demirel, 2007; Dowden, 2017). Learner-centered designs revolve around making sure that students recognize their own creativity and improving their skills in this area (Adegbile \& Farombi, 1999, Emes \& Cleveland-Innes, 2003). In other words, as Dewey (2007) also pointed out, learner-centered designs provide students with a variety of learning opportunities and environments that allow them to make use of their own experiences in order to create learning products. Thusly, it can be asserted that learner-centered designs can be associated with progressivism and existentialism as philosophical movements (Baş \& Şentürk, 2019). Another approach to curriculum design is problem-centered design, which places the focus of curricula squarely on sociological problems and issues. As in learner-centered designs, problem-centered designs adopt an approach that puts individuals in the center of the process (Ornstein \& Hunkins, 2014). In addition, the main purpose of this approach is to make sure that learners play an active role in addressing and resolving sociological issues (Tucker, 2011). Similar to learner-centered design, the philosophy underlying problem-centered design contains elements of modern philosophies of education (Kozikoğlu \& Uygun, 2018). In summary, it is understood that there are three approaches to curriculum design based on various philosophical foundations. While there are, educational views of traditional philosophical movements based on the subject-centered curriculum design

E-Vhuslararase Ĕğtim Ahașturmalare Dergisi

ISSN: 1309-6265, Cilt: 12, No: 4, ss. 20-40 
approach, there are educational views of contemporary philosophical movements based on student and problem-centered curriculum designs.

Teachers' approaches to curriculum design play an important role in the functionality of the teaching and learning process (Baş, 2014). An examination of the relevant literature provides ample evidence of this fact. Indeed, two studies (Baş \& Şentürk, 2019; Kozikoğlu \& Uygun, 2018) determined that there were significant relationships between educational philosophies adopted by teachers and their preferred approaches to curriculum design. These studies revealed that teachers who adopted traditional philosophies of education were found to prefer subjectcentered designs, while those who embraced modern philosophies of education were more likely to prefer learner-centered and problem-centered designs. A study conducted by Burul (2018) suggested that teachers' approaches to curriculum design affect their curriculum fidelity; based on the findings gathered from said study, teachers who preferred learner-centered curriculum design have higher levels of curriculum fidelity. In other words, teachers' approaches to curriculum design play a major role in the proper implementation and delivery of the curricula as they were originally designed. Thus, their approaches to curriculum design may affect their style (traditional or modern) of classroom management and the way they manage the teaching and learning process.

In addition to the view that evaluates classroom management from the perspective of the management of the class organization, it can be said that it is often seen as the management of course or of teaching (Toprakçı, 2002; Toprakçı, 2012; Toprakçı, 2017). Based on this second meaning, classroom management refers to a variety of actions and strategies that teachers use to keep students organized and on task during a class (Scrivener, 2012). In other words, classroom management is a process that allows classroom activities to be carried out efficiently in a proper teaching and learning environment (Evertson \& Weinstein, 2006; Turan, 2019). Within this purview, classroom management can be divided into two categories: traditional and modern. In traditional classroom management, teachers are the designated decision makers when it comes to organizing the classroom environment, creating classroom rules, and designing learning experiences, while modern classroom management enables both teachers and students to become participants in the teaching and learning process. Hence, modern classroom management creates a democratic classroom atmosphere (Aydın, 2019). The degree to which teachers adopt these approaches determines, to a large extent, different classroom management styles (Ekici, 2004). Classroom management styles can be grouped into four major categories: authoritative, permissive, authoritarian and uninvolved (Bosworth, 1997).

Teachers who adopted an authoritative classroom management style follow a disciplined approach in the learning-teaching process, but the understanding of discipline is not at the level that puts pressure on the student. Teachers set certain rules in the classroom environment and explain the reason for these rules to students. However, the teacher defends the student's autonomy (Bosworth, 1997). Teachers who adopted a permissive classroom management style pay as much attention to students' emotional states as possible. In this context, students' ideas are valued (Arisena, 2010). Teachers who have an authoritarian classroom management style are the only ones who have authority in the regulation and operation of the learning-teaching process. Teachers do not consider the student's ideas in the functioning of the learning-teaching process. The rules determined by the teachers in the classroom are unquestionable. There is no flexibility for students to comply with these rules (Ekici, 2004). Teachers who have an uninvolved classroom management style do not show the necessary interest and sensitivity about the

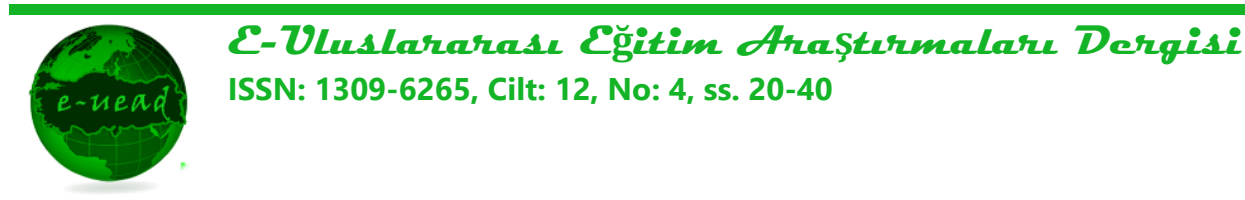


efficiency of the learning-teaching process. The presence or absence of the teacher in the classroom environment is unclear (Moore, 1989).

The classroom management styles that teachers adopt are considered to be important in the teaching and learning process (Ekici, 2004; Sezer et al., 2017). The results of studies in the relevant literature were found to dovetail with this conclusion. A study conducted by Aytaç and Uyangör (2020) reveal that there is a statistically significant relationship between teachers' classroom management styles and their perspectives on teaching. Thus, teachers who make use of traditional methods of teaching are more likely to adopt an authoritarian classroom management style, while teachers who make use of modern methods of teaching are more likely to embrace both permissive and authoritative classroom management styles. A Study carried out by Debbağ and Fidan (2020) indicate that there are statistically significant relationships between teachers' classroom management styles and their attitudes towards multicultural education. The authoritative classroom management style was found to play an important role in determining teachers' attitudes toward multicultural education. A Study done by Aluçdibi and Ekici (2012) revealed that teachers' classroom management styles are found to be an important factor in shaping the extrinsic motivation of students under their supervision.

As a consequence, both teachers' approaches to curriculum design and their classroom management styles can be considered critical variables during the teaching and learning process. There have been various studies encountered in the relevant body of literature where relationships between teachers' approaches to curriculum design and a number of other variables such as their curriculum fidelity (Burul, 2018), their predispositions regarding the philosophy of education (Bas \& Şentürk, 2019; Doğan-Dolapçıoğlu, 2020; Kozikoğlu \& Uygun, 2018), classroom activities for teaching critical thinking skills (Pehlivan and Şahin-Taşkın, 2020), and beliefs regarding the profession of teaching and personal responsibility (Eren \& Çetin, 2019) were scrutinized. In addition, there are a number of studies (Baş, 2014; Cheung \& Ng, 2000; Jenkins, 2009; Karaman \& Bakaç, 2018; Şahin, 2020; Tanrıverdi \& Apak, 2013; Ünsal \& Korkmaz, 2017) in which teachers' approaches to curriculum design were examined as the sole variable. There are also a large number of studies where the relationship between teachers' classroom management styles and many other variables such as pupil control ideologies (YIlmaz, 2009), perceptions of democratic values (Yılmaz, 2011), attitudes towards the rights of the child (Dönmez, 2015), lifestyles (Sezer et al., 2017), and attitudes towards multicultural education (Debbağ \& Fidan, 2020) was investigated. In addition, there are a number of studies (Beyleroğlu et al., 2017; Ekici, 2004; Ekici et al., 2012; Sadık \& Sadık, 2013) in which teachers' classroom management styles were examined as the sole variable. However, no studies that examine the relationship between teachers' approaches to curriculum design and classroom management styles have been encountered in the current body of literature; for this reason, it is considered that an analysis of the relationship between these two variables will provide researchers with different perspectives on this issue. Yet, teachers' roles and responsibilities have changed in accordance with the underlying philosophies of the curricula that have been in effect since the 2005-2006 academic year; teachers are expected to adopt learnercentered education practices and employ relevant approaches in their classroom. According to Jenkins (2009), teachers' perspectives on the curriculum can affect their classroom practices. In this respect, determining the approaches to curriculum design preferred by teachers can affect their classroom practices and give clues about which classroom management style they have. As a matter of fact, according to Baş (2013), examining teachers' approaches to curriculum design can provide information about their perspectives and practices regarding the learning-teaching process. In this context, which approaches to curriculum design teachers adopt can provide some

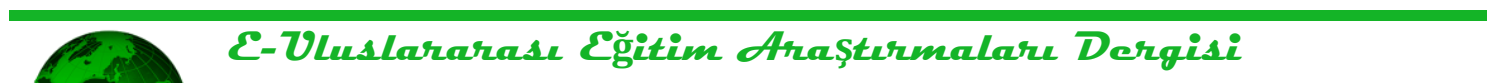


indicators about the curriculum being implemented. It is thought that the results of this study will provide ample information for authorities that shape national policies on education and teachers. In this context, the results of this study can be a guide for experts who design in-service training programs. Thus, the purpose of this study is to analyze the relationship between teachers' approaches to curriculum design and classroom management styles. Within this context, answers to the following questions were sought:

1. What types of curriculum design approaches and classroom management styles do teachers adopt?

2. Is there a statistically significant relationship between teachers' approaches to curriculum design and their classroom management styles?

3. Do teachers' approaches to curriculum design significantly predict their classroom management styles?

\section{METHOD}

As the aim of this study was to examine the relationship between teachers' approaches to curriculum design and their classroom management styles, a correlational survey model was used. Karasar (2006) noted that the correlational survey model, a type of survey model, investigates both the degree and direction of the relationship between two or more variables. In other words, correlational survey models are used in order to determine whether or not two or more variables have an effect on each other (Tekbıyık, 2014).

The sample of this study consisted of 334 teachers who volunteered to participate and were working in public schools in Turkey during the 2020-2021 academic year. According to the sample size table of Yazıcıoğlu and Erdoğan (2004), it is seen that the sample size in this study is insufficient at the $95 \%$ confidence interval, whereas it is sufficient at the $90 \%$ confidence interval. It is possible to say that the reason why the larger sample size could not be reached in this study is the difficulty in reaching the participants during the Covid-19 process. The sampling method employed was convenient sampling. The convenient sampling method, which is one of the nonrandom sampling methods, is used to prevent loss of time, money and labor (Büyüköztürk et al., 2008). $68.3 \%$ (228) of the teachers who participated in the study was female, while $31.7 \%(106)$ was male. $38.6 \%$ (129) of the teachers had between zero to ten years of work experience, $38.9 \%$ (130) had between eleven and twenty years, and 22.5\% (75) had twenty-one years or more. $23.4 \%$ (78) of the teachers worked in elementary schools, $47 \%$ (157) worked in middle schools, and $26.6 \%$ (99) worked in high schools.

\section{Data Collection Tools}

Approaches to Curriculum Design Scale (ACDS): The Approaches to Curriculum Scale was developed by Baş (2013), and the evaluation group of the scale consisted of 300 teachers. After conducting exploratory factor analysis (EFA), a scale with three dimensions and thirty items was created; the scale accounted for $52 \%$ of the total variance, and it is a 5-point Likert scale. Afterwards, this structure with three factors was subjected to confirmatory factor analysis (CFA) using another sample $(\mathrm{CMIN} / \mathrm{DF}=604.02 / 402 ; \mathrm{GFI}=0.83 ; \mathrm{AGFI}=0.80 ; \mathrm{RMSEA}=0.05 ; \mathrm{CFI}=0.90$; $\mathrm{NFI}=0.77 ; \mathrm{NNFI}=0.89 ; \mathrm{RMR}=0.056 ; \mathrm{SRMR}=0.077]$, and it was confirmed that the scale has three

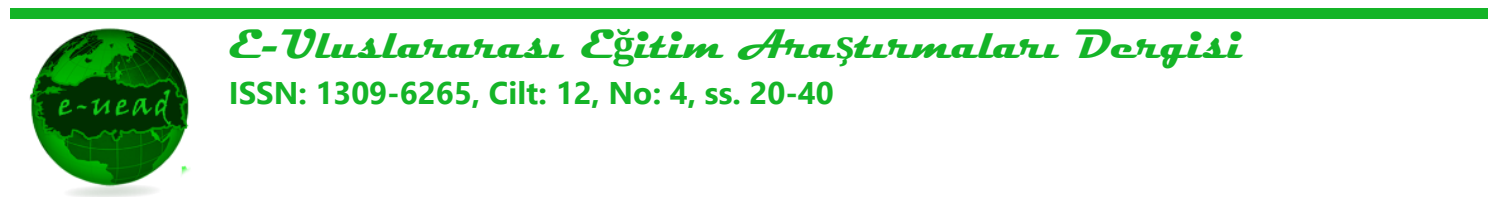


dimensions; these dimensions were referred to as Subject-Centered Design (SCD), LearnerCentered Design (LCD), and Problem-Centered Design (PCD). After performing reliability analyses, the Cronbach's alpha value of the entire scale was found to be 0.94 , and it was calculated to be 0.89 for the SCD dimension, 0.89 for the LCD dimension, and 0.87 for the PCD dimension. Also, the Spearman-Brown prophecy formula was used to measure the reliability of the test scores, and it was calculated to be 0.91 . Each dimension includes ten items. In the reliability analysis performed within the scope of this study, the Cronbach's alpha value of the entire scale was found to be 0.79 , and it was calculated to be 0.68 for the SCD dimension, 0.86 for the LCD dimension, and 0.79 for the PCD dimension.

Classroom Management Styles Scale (CMSS): The evaluation group of the scale, which was developed by Bosworth (1997) and adapted by Aktan and Sezer (2018) for use in a Turkish cultural context, consisted of 306 teachers. The linguistic equivalence of the scale was evaluated, and further relevant analyses were then conducted. After performing item analysis, item discrimination indices were found to be at an acceptable level. Also, the reliability analysis generated values that fell within an acceptable range. After subjecting the scale to EFA, a scale with four dimensions and twelve items was created. The scale, a 5-point Likert scale, accounted for $66 \%$ of the total variance. After conducting CFA (CMIN/DF $=2.39, \mathrm{RMSEA}=.068, \mathrm{CFI}=1.00$, $\mathrm{NNFI}=1.00, \mathrm{GFI}=.99$ ), it was confirmed that the scale had four dimensions; these dimensions were referred to as Authoritarian Classroom Management Style (ACMS), Authoritative Classroom Management Style (AVCMS), Permissive Classroom Management Style (PCMS), and Uninvolved Classroom Management Style (UCMS). Each dimension has three items. After performing reliability analyses, the Cronbach's alpha value of the entire scale was found to be 0.82 , and it was calculated to be 0.68 for the ACMS dimension, 0.70 for the AVCMS dimension, 0.75 for the PCMS dimension, 0.76 for the UCMS dimension. The Spearman-Brown value of the entire scale was found to be 0.69 , and it was calculated to be 0.73 for the ACMS dimension, 0.69 for the AVCMS dimension, .71 for the PCMS dimension, 0.72 for the UCMS dimension. In the reliability analysis performed within the scope of this study, the Cronbach's alpha value of the entire scale was found to be 0.78 , and it was calculated to be 0.71 for the ACMS dimension, 0.68 for the AVCMS dimension, 0.76 for the PCMS dimension, 0.72 for the UCMS dimension.

Data Collection and Analysis: In the first half of January 2021, data was collected digitally through social media due to the COVID-19 pandemic. Within this context, a total of 357 pieces of data were collected and entered into a software program for analysis. The data set was first checked for extreme values, and twenty-three pieces of data were subsequently removed from the data set. The Mahalanobis distance was used to check for the presence of multi-dimensional extreme values. Afterwards, measures of kurtosis (SCD: .532, LCD: -.395, PCD: -.075, ACMS: -.040, AVCMS: -.635, PCMS: .017, UCMS: .616) and skewness (SCD: .289, LCD: -.451, PCD: -.656, ACMS: .226, AVCMS: -.373, PCMS: .053, UCMS: .357) for the data were examined, and it was found that the values fell within acceptable ranges. Thusly, the data set was analyzed using descriptive statistics (arithmetic mean and standard deviation), Pearson's correlation coefficient, and multiple regression analysis. In order to perform regression analysis, a variety of requirements needs to be taken into consideration; one of these requirements is the elimination of the multicollinearity problem. In other words, no high intercorrelation should occur between two or more independent variables in a multiple regression model. After performing correlation analysis, the highest intercorrelation among three independent variables was calculated to be 0.738 . Büyüköztürk (2007) states that the intercorrelation among independent variables must be at least 0.80 in order to start discussing the problem of multicollinearity. Other methods used to detect multicollinearity

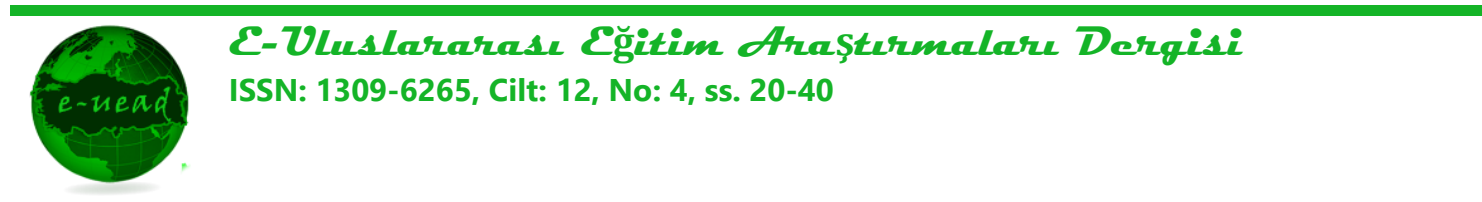


are checking both the value of tolerance and the variance inflation factor (VIF) (Çokluk et al., 2014). If the value of tolerance is above 0.20 and, simultaneously, the value of VIF is below 10 , then multicollinearity is not an issue (Field, 2005). Keeping this in mind, our findings from various analyses showed that there is no multicollinearity among the independent variables.

Both scales used in this study are 5-point Likert scales, and, therefore, interval values were designated after analyzing the data set. Tekin's (2002) formula was used to calculate the scale interval value ranges. Values between 1.00 and 1.79 were considered very low, 1.80 and 2.59 low, 2.60 and 3.39 moderate, 3.40 and 4.19 high, and 4.20 and 5.00 very high. In addition, the Pearson's correlation coefficient was calculated, and if the coefficient value was less than 0.30 , the degree of correlation was considered low; if it was between 0.30 and 0.69 , it was considered moderate; and if it was 0.70 or higher, it was considered high (Çokluk et al., 2014).

\section{FINDINGS}

In this section, the study findings are listed in the same order as the study questions. The data sets that include arithmetic mean and standard deviation values will be touched upon first. Findings gathered from the correlation analysis among variables will be introduced second, and finally, multiple regression analysis results will be presented and discussed.

\section{Findings of the Study's First Question:}

The descriptive statistics data sets (arithmetic mean and standard deviation) from both the teachers' approaches to the curriculum design sub-dimension and the teachers' classroom management styles sub-dimension are presented in this section. Table 1 below contains relevant data from this analysis.

Table 1. Descriptive Statistics Data on Variables

\begin{tabular}{lccccc}
\hline Sub-dimensions & $\mathbf{N}$ & Minimum & Maximum & Mean & $\begin{array}{c}\text { Standard } \\
\text { Deviation }\end{array}$ \\
\hline Subject-Centered Design (SCD) & 334 & 1.50 & 4.70 & 2.83 & .53 \\
Learner-Centered Design (LCD) & 334 & 3.10 & 5.00 & 4.36 & .41 \\
Problem-Centered Design (PCD). & 334 & 3.00 & 5.00 & 4.46 & .41 \\
Authoritarian Classroom Management Style (ACMS) & 334 & 1.00 & 5.00 & 2.87 & .71 \\
Uninvolved Classroom Management Style (UCMS). & 334 & 1.00 & 5.00 & 2.49 & .66 \\
Authoritative Classroom Management Style (AVCMS) & 334 & 2.67 & 5.00 & 4.26 & .57 \\
Permissive Classroom Management Style (PCMS) & 334 & 1.00 & 5.00 & 3.25 & .69 \\
\hline
\end{tabular}

The findings presented in Table 1 above contain the descriptive statistics data sets. Based on these sets, the mean of the SCD sub-dimension (Mean $=2.83$, Standard Deviation $(S D)=0.53$ ) was found to be at a moderate level, while mean values of the LCD (Mean=4.36, SD=0.41) and PCD (Mean $=4.46, S D=0.41)$ sub-dimensions were found to be at very high levels. Mean values for the UCMS (Mean=2.49, SD=0.66), ACMS (Mean=2.87, SD=0.71), PCMS (Mean=3.25, SD=0.69), and 
AVCMS (Mean=4.26, SD=0.57) were found to be at a low, moderate, moderate, and very high level respectively.

\section{Findings of the Study's Second Question:}

The Pearson's correlation coefficient values for both the teachers' approaches to the curriculum design sub-dimension and the teachers' classroom management styles sub-dimension are introduced in this section. Table 2 below contains relevant data from this analysis.

Table 2. Correlation Analysis results

\begin{tabular}{|c|c|c|c|c|}
\hline & ACMS & AVCMS & PCMS & UCMS \\
\hline SCD & $.306^{\star \star *}$ & $-.101^{*}$ & $-.064^{*}$ & $.183^{\star \star \star}$ \\
\hline LCD & 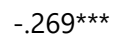 & $.464^{\star \star \star}$ & $.292^{\star \star \star}$ & $-.056^{\star}$ \\
\hline PCD & -.129 ** & $.437^{\star \star \star}$ & $.208^{\star \star \star}$ & $-.099 *$ \\
\hline
\end{tabular}

The correlation analysis results displayed in Table 2 above reveal that there is a positive, moderate relationship between the SCD sub-dimension and the ACMS sub-dimension $(r=0.306$, $p<0.01)$, while the relationship between SCD and UCMS $(r=0.183, p<0.01)$ was found to be positive and at a low level. However, there is no statistically significant relationship found between the SCD sub-dimension and AVCMS $(r=-0.101, p>0.05)$ or PCMS $(r=-0.064, p>0.05)$. Also, there is a negative, moderate relationship between the LCD sub-dimension and ACMS ( $r=-0.269$, $p<0.01$ ), while the relationship was found to be positive and at a moderate level between LCD and AVCMS $(r=0.464, p<0.01)$ and positive and at a low level between LCD and PCMS $(r=0.292$, $p<0.01$ ). There is no statistically significant relationship between the LCD sub-dimension and the UCMS sub-dimension ( $r=-0.056, p>0.05)$. The PCD sub-dimension was found to have a negative, low relationship with the ACMS sub-dimension $(r=-0.129, p<0.05)$, a positive and moderate with the AVCMS sub-dimension $(r=0.437, p<0.01)$; and positive and low with the PCMS sub-dimension $(r=0.208, p<0.01)$. However, there is no statistically significant relationship between the PCD and UCMS ( $r=-0.099, p>0.05)$ sub-dimensions.

\section{Findings of the Study's Third Question:}

This section includes information regarding the degree to which teachers' approaches to curriculum design sub-dimensions predict their classroom management styles. The results of multivariate regression analysis are shown in four separate tables that line up with the number of sub-dimensions of the dependent variable (teachers' classroom management styles). The VIF and Tolerance values that emerged as a result of the analysis examining the predictive effect of approaches to curriculum design on classroom management styles are presented in Table 3 below.

Table 3. The VIF and Tolerance values of the predictive effect of approaches to curriculum design on classroom management styles

\begin{tabular}{lcc}
\hline Dimensions & Tolerans & VIF \\
\hline SCD & .977 & 1.023 \\
LCD & .499 & 2.225 \\
PCD & .445 & 2.246 \\
\hline
\end{tabular}


When the VIF and Tolerance values presented in Table 3 above are examined, it can be said that there is no multicollinearity problem in the data. Table 4 below contains data regarding the degree to which the teachers' approaches to curriculum design sub-dimensions predict the classroom management style sub-dimensions.

Table 4. Analysis results on the prediction of Authoritarian Classroom Management Styles (ACMS) sub-dimension

\begin{tabular}{cccccccc}
\hline & $\mathbf{B}$ & $\begin{array}{c}\text { Standard } \\
\text { Error }\end{array}$ & $\boldsymbol{\beta}$ & $\mathbf{t}$ & $\mathbf{p}$ & $\begin{array}{c}\text { Zero } \\
\text { order (r) }\end{array}$ & Partial (r) \\
\hline Constant & 3.3554 & .443 & & 8.016 & .000 & & \\
SCD & .394 & .068 & .295 & 5.806 & .000 & .306 & .304 \\
LCD & -.566 & .128 & -.332 & -4.432 & .000 & -.269 & -.237 \\
PCD & .151 & .130 & .088 & 1.165 & .245 & -.129 & .064 \\
\hline $\mathrm{R}=.410-\mathrm{F}_{(3-330)}=22.238-\mathrm{R}^{2}=.168-\mathrm{p}=.000$ & & & & &
\end{tabular}

As shown in Table 4 above, the relationship between sub-dimensions of teachers' approaches to curriculum design and the ACMS sub-dimension was found to be statistically significant and at a moderate level $\left(R=0.410, R^{2}=0.168, F_{(3-330)}=22.238, p<0.01\right)$. Taken as a whole, the sub-dimensions of teachers' approaches to curriculum design account for $17 \%$ of the variance of the ACMS sub-dimension. An analysis of standardized regression coefficients showed the relative effect of teachers' approaches to curriculum sub-dimensions on the ACMS subdimension. The sub-dimensions were put in order based on their relative importance: the LCD ( $\beta=$ -0.332), SCD ( $\beta=0.295)$, and PCD ( $\beta=0.088)$. The results gathered from the test for significance of regression revealed that $S C D$ and $L C D$ sub-dimensions were found to have a statistically significant effect on the ACMS ( $p<0.01$ ), while the PCD sub-dimension wasn't found to have any statistically significant predictive effect on the ACMS sub-dimension ( $p>0.05)$. Partial correlations between predictive variables and the predicted variable were examined, and the value of partial correlation was found to be $r=0.304$ between the ACMS and the SCD, r = -0.237 between the ACMS and the LCD, and $r=0.064$ between the ACMS and the PCD. The regression equation that measures the effect of the teachers' approaches to curriculum design sub-dimensions on the authoritarian classroom management style sub-dimension is shown below:

$$
\text { ACMS }=(0.394 \times S C D)+(-0.566 \times L C D)+(0.151 \times P C D)
$$

Table 5 below contains data regarding the degree to which teachers' approaches to curriculum design sub-dimensions predict the uninvolved classroom management style subdimension.

Table 5. Analysis results on the prediction of the Uninvolved Classroom Management Style (UCMS) sub-dimension

\begin{tabular}{cccccccc}
\hline & $\mathbf{B}$ & $\begin{array}{c}\text { Standard } \\
\text { Error }\end{array}$ & $\boldsymbol{\beta}$ & $\mathbf{t}$ & $\mathbf{p}$ & $\begin{array}{c}\text { Zero } \\
\text { order (r) }\end{array}$ & Partial (r) \\
\hline Constant & 2.515 & .441 & & 5.698 & .000 & & \\
SCD & .248 & .067 & .200 & 3.679 & .000 & .183 & .199 \\
LCD & .115 & .127 & .072 & .905 & .366 & -.056 & .050 \\
PCD & -.276 & .129 & -.172 & -2.136 & .033 & -.099 & -.117 \\
\hline $\mathrm{R}=.222-\mathrm{F}_{(3-330)}=5.728-\mathrm{R}^{2}=.049-\mathrm{p}=.001$ & & & & &
\end{tabular}

As shown in Table 5 above, the relationship between sub-dimensions of teachers' approaches to curriculum design and the UCMS sub-dimension was found to be statistically

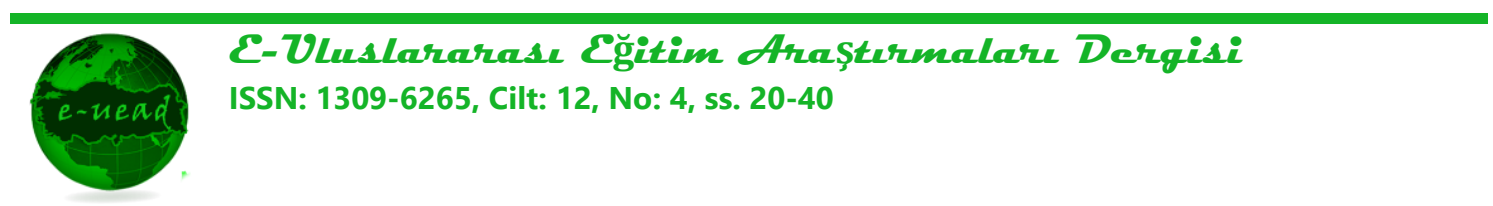


significant and at a low level $\left(R=0.222, R^{2}=0.049, F_{(3-330)}=5.728, p<0.01\right)$. Taken as a whole, the sub-dimensions of teachers' approaches to curriculum design account for $5 \%$ of the variance of the UCMS sub-dimension. An analysis of standardized regression coefficients showed the relative effect of teachers' approaches to curriculum sub-dimensions on the UCMS sub-dimension. The sub-dimensions were put in order based on their relative importance: the SCD $(\beta=0.200), P C D$ $(\beta=-0.172)$, and $L C D(\beta=0.072)$. The results gathered from the test for significance of regression revealed that two of the predictive variables, specifically the SCD $(p<0.01)$ and $P C D(p<0.05)$ subdimensions, were found to have a statistically significant effect on the UCMS, while the LCD subdimension wasn't found to have any statistically significant predictive effect on the UCMS subdimension $(p>0.05)$. Partial correlations between predictive variables and the predicted variable were examined, and the value of partial correlation was found to be $r=0.199$ between the UCMS and the SCD, $r=0.050$ between the UCMS and the LCD, and $r=-0.117$ between the UCMS and the $P C D$. The regression equation that measures the effect of teachers' approaches to curriculum design sub-dimensions on the uninvolved classroom management style sub-dimension is shown below:

$$
\text { UCMS }=(0.248 \times S C D)+(0.115 \times L C D)+(-0.276 \times P C D)
$$

Table 6 below contains data regarding the degree to which teachers' approaches to curriculum design sub-dimensions predict the authoritative classroom management style subdimension.

Table 6. Analysis results on the prediction of the Authoritative Classroom Management Styles (AVCMS) sub-dimension

\begin{tabular}{cccccccc}
\hline & $\mathbf{B}$ & $\begin{array}{c}\text { Standard } \\
\text { Error }\end{array}$ & $\boldsymbol{\beta}$ & $\mathbf{t}$ & $\mathbf{p}$ & $\begin{array}{c}\text { Zero } \\
\text { order (r) }\end{array}$ & Partial (r) \\
\hline Constant & 1.430 & .340 & & 4.201 & .000 & & \\
SCD & -.131 & .052 & -.121 & -2.517 & .012 & -.101 & -.137 \\
LCD & .398 & .098 & .289 & 4.060 & .000 & .464 & .218 \\
PCD & .328 & .099 & .236 & 3.299 & .001 & .437 & .179 \\
\hline
\end{tabular}

$\mathrm{R}=.499-\mathrm{F}_{(3-330)}=36.527-\mathrm{R}^{2}=.249 \mathrm{p}=.000$

As shown in Table 6 above, the relationship between sub-dimensions of teachers' approaches to curriculum design and the AVCMS sub-dimension was found to be statistically significant and at a moderate level $\left(R=0.499, R^{2}=0.249, F_{(3-330)}=36.527, p<0.01\right)$. The subdimensions of teachers' approaches to curriculum design account for $25 \%$ of the variance of the AVCMS sub-dimension. An analysis of standardized regression coefficients showed the relative effect of teachers' approaches to curriculum sub-dimensions on the AVCMS sub-dimension. The sub-dimensions were put in order based on their relative importance: the LCD $(\beta=0.289), P C D$ $(\beta=0.236)$, and $\operatorname{SCD}(\beta=-0.121)$. The results gathered from the test for significance of regression revealed that three predictive variables, the SCD $(p<0.05)$, LCD $(p<0.01)$, and PCD $(p<0.01)$ subdimensions, were found to have a statistically significant effect on the AVCMS sub-dimension. Partial correlations between predictive variables and the predicted variable were examined, and the value of partial correlation was found to be $r=-0.137$ between the AVCMS and the SCD, $r=$ 0.218 between the AVCMS and the LCD, and $r=0.179$ between the AVCMS and the PCD. The regression equation that measures the effect of teachers' approaches to curriculum design subdimensions on the authoritative classroom management style sub-dimension is shown below:

$$
\text { AVCMS }=(-0.131 \times S C D)+(0.398 \times L C D)+(0.328 \times P C D)
$$

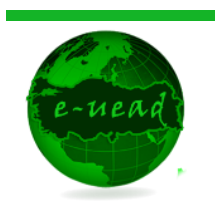


Table 7 below contains data regarding the degree to which teachers' approaches to curriculum design sub-dimensions predict the permissive classroom management style subdimension.

Table 7. Analysis results on the prediction of the Permissive Classroom Management Style (PCMS) sub-dimension

\begin{tabular}{cccccccc}
\hline & $\mathbf{B}$ & $\begin{array}{c}\text { Standard } \\
\text { Error }\end{array}$ & $\boldsymbol{\beta}$ & $\mathbf{t}$ & $\mathbf{p}$ & $\begin{array}{c}\text { Zero } \\
\text { order }(\mathbf{r})\end{array}$ & Partial (r) \\
\hline Constant & 1.344 & .456 & & 2.946 & .003 & & \\
SCD & -.081 & .070 & -.062 & -1.162 & .246 & -.064 & -.064 \\
LCD & .495 & .132 & .295 & 3.764 & .000 & .292 & .203 \\
PCD & -.007 & .133 & -.004 & -.049 & .961 & .208 & -.003 \\
\hline $\mathrm{R}=.299-\mathrm{F}_{(3-330)}=10.800-\mathrm{R}^{2}=.089-\mathrm{p}=.000$ & & & & &
\end{tabular}

As shown in Table 7 above, the relationship between sub-dimensions of teachers' approaches to curriculum design and the PCMS sub-dimension was found to be statistically significant and at a low level $\left(R=0.299, R^{2}=0.089, F_{(3-330)}=10.800, p<0.01\right)$. The sub-dimensions of teachers' approaches to curriculum design account for $9 \%$ of the variance of the PCMS subdimension. An analysis of standardized regression coefficients showed the relative effect of teachers' approaches to curriculum sub-dimensions on the PCMS sub-dimension. These subdimensions were put in order based on their relative importance: the LCD $(\beta=0.295), \operatorname{SCD}(\beta=-$ $0.062)$, and PCD $(\beta=-0.004)$. The results gathered from the test for significance of regression revealed that one of the predictive variables, $L C D$, was found to have a statistically significant effect on the PCMS sub-dimension $(p<0.01)$, while the SCD and PCD sub-dimensions weren't found to have any statistically significant predictive effects on the PCMS sub-dimension ( $p>0.05)$. Partial correlations between predictive variables and the predicted variable were examined, and the value of partial correlation was found to be $r=-0.064$ between the PCMS and the SCD, $r=$ 0.203 between the PCMS and the LCD, and $r=-0.003$ between the PCMS and the PCD. The regression equation that measures the effect of teachers' approaches to curriculum design subdimensions on the permissive classroom management style sub-dimension is shown below:

$$
\text { PCMS }=(-0.081 \times S C D)+(0.495 \times L C D)+(-0.007 \times P C D)
$$

\section{DISCUSSION, CONCLUSION AND RECOMMENDATIONS}

The relationship between teachers' approaches to curriculum design and their classroom management styles was analyzed in this study. Within this context, descriptive statistics data sets were first discussed, and Pearson's correlation coefficients values were subsequently touched upon. Afterwards, the results obtained from regression analysis, which examines the predictive effect of teachers' approaches to curriculum design sub-dimensions on their classroom management styles, were discussed. Finally, a variety of recommendations was made in accordance with the results obtained.

Within the framework of the first question of the study, the types of curriculum design approaches adopted by teachers were examined initially; the subject-centered design (SCD) subdimension was found to be moderately preferred by teachers, while the degree of preference for both the learner-centered design (LCD) and problem-centered design (PCD) sub-dimensions was found to be very high. Thus, it is evident that teachers tend to prefer curriculum designs that place 
the focus on the learners and their problem-solving skills during the teaching and learning process. In other words, teachers hardly likely put particular attention to coursebooks, and therefore, subjects to be taught during the teaching and learning process. Teachers' preference for learner-centered design can be attributed to the fact that the fundamentals of the educational philosophy that underpin the curricula (which have been in effect since the 2006 academic year) align with the principles of learner-centered education. Results gathered from previous studies (Baş, 2014; Burul, 2018; Karaman \& Bakaç, 2018; Kozikoğlu \& Uygun, 2018; Pehlivan \& ŞahinTaşkın, 2020; Ünsal \& Korkmaz, 2017) in the relevant literature dovetailed with the results of our study. Secondly, teachers' classroom management styles were examined within the context of the first question of the study. Teachers' inclinations toward adopting the UCMS sub-dimension were found to be at a low level, while they were found to be at a moderate level for both the ACMS and PCMS sub-dimensions and at a very high level for the AVCMS sub-dimension. Thus, it is clear that teachers display an inclination toward creating democratic classroom environment where students are placed front and center. In other words, teachers tend to embrace a collaborative classroom management style based on a reciprocal student-teacher relationship; they also tend to create a classroom atmosphere where students are allowed to have a voice rather than establish a domineering, oppressive atmosphere during the learning and teaching process. The reason that teachers might be more likely to embrace the authoritative classroom management style is that they have had a particular role laid out for them by national curricula, which have been in effect since 2005. Özden (2014) notes that, according to the philosophy that underlies these continuallyrevamped curricula, the role of teachers during the teaching and learning process should be that of a leader or guide rather than an instructor. Similar results were found after reviewing previous studies (Barroso \& Dias, 2020; Berger \& Girardet, 2020; Debbağ \& Fidan, 2020; Aluçdibi \& Ekici, 2012; Ekici et al., 2012; McGinty, 2000; Sadık \& Sadık, 2013; Talşık, 2015; Yılmaz, 2009) in the relevant literature.

The relationship between teachers' approaches to curriculum design and their classroom management styles was examined within the context of the second question of the study, and statistically significant relationships were found between teachers' approaches to curriculum design and classroom management styles. Accordingly, the relationship between the SCD and ACMS sub-dimensions was found to be positive and at a moderate level, while there was a low, positive relationship found between the SCD and UCMS sub-dimensions. In addition, the relationship between the LCD and ACMS sub-dimensions was found to be negative and at a moderate level, while there was a moderate, positive relationship found between the LCD and AVCMS sub-dimensions and a low, positive relationship between the LCD and PCMS subdimensions. The relationship between the PCD and ACMS sub-dimensions was found to be negative and at a low level, while there was a moderate, positive relationship found between the PCD and AVCMS sub-dimensions and a low, positive relationship between the PCD and PCMS sub-dimensions. Based on the results of this study, it can be stated that there are parallels between teachers' preferred approaches to curriculum design and their adopted classroom management styles. A study conducted by Baş and Şentürk (2019) revealed that subject-centered designs are closely associated with traditional philosophies of education, while both learner-centered and problem-centered designs are significantly connected to modern philosophies of education. In the study of Börekçi and Uyangör (2021), significant relationships were found between educational philosophical preferences and approaches to curriculum design. According to the results of this study, educational philosophical preferences significantly predict approaches to curriculum design. In other words, it is possible to say that educational philosophical preferences

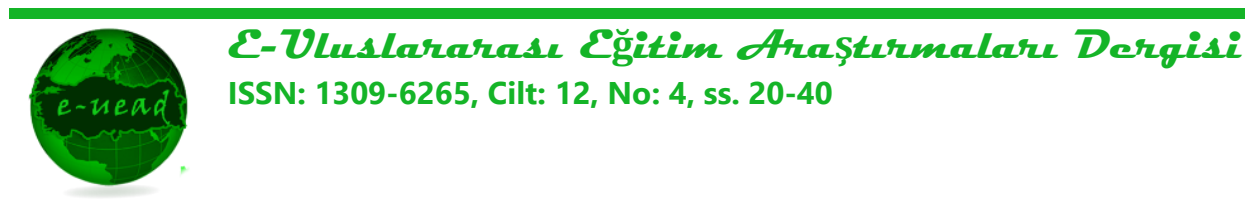


have a significant impact on the understanding of approaches to curriculum design. Educational philosophical preferences have also an influence on teaching approaches (Baş, 2015). In the study of Aslan (2018), it was determined that traditional educational philosophical preferences predict traditional teaching approaches, while contemporary educational philosopical preferences predict contemporary teaching approaches. A study carried out by Aytaç and Uyangör (2020) showed that there is a positive relationship between modern education methods and both the authoritative and permissive classroom management styles, while there is also a positive relationship between traditional education methods and both the authoritarian and uninvolved classroom management styles. In addition, in the study of YIlmaz (2011), significant relationships were found between teachers' views on democratic values and classroom management styles. Accordingly, there is a positive and significant relationship between teachers' views on democratic values and authoritative classroom management styles and permissive classroom management styles. According to Ornstein and Hunkins (2014), one of the educational principles of learnercentered and problem-centered curriculum designs is the understanding of democratic classroom management. A holistic review of the results of this study shows that these claims regarding the relationship between approaches to curriculum design and classroom management styles are well-supported by the relevant literature and current theoretical frameworks.

Within the context of the third question of the study, teachers' approaches to curriculum design were found to significantly predict classroom management styles. The subject-centered design (SCD) sub-dimension was found to positively predict both the ACMS and UCMS subdimensions, while it negatively and significantly predicted the AVCMS sub-dimension. The learner-centered design (LCD) sub-dimension was found to negatively predict the ACMS subdimension, while it positively and significantly predicted both AVCMS and PCMS sub-dimensions. The problem-centered design (PCD) sub-dimension, on the other hand, was found to negatively predict the UCMS sub-dimension, while it positively predicted the AVCMS sub-dimension. Keeping these findings in mind, it can be stated that teachers' approaches to curriculum design play an important role in understanding their classroom management styles, e.g., teachers who adopt a subject-centered design tend to possess authoritarian and/or uninvolved classroom management styles. In other words, teachers who claim that subjects and coursebooks must be the center of the teaching and learning process were found to display domineering and authoritarian behavior in the classroom. Sönmez (2001) notes that subject-centered design, which is based on idealist philosophies, puts the focus on subjects that need to be included in curriculum content. Results gathered from a study carried out by Kozikoğlu and Uygun (2018) revealed that traditional philosophies of education constitute the basis for subject-centered designs. Teachers whose educational approaches are based on traditional philosophies are the absolute authorities and sole decision-makers in their classroom (Ellis, 2015; Gutek, 2006). Moreover, teachers who have adopted learner-centered and problem-centered designs are more likely to have an authoritative classroom management style. Teachers who claim that students' needs and interests should be centered in the teaching and learning process build genuine relationships with their students in a classroom setting and provide them with learning experiences that allow them to learn through their own experiences. Ornstein and Hunkins (2014) stated that modern philosophies of education are the basis for both learner-centered and problem-centered curriculum designs; a study conducted by Baş and Şentürk (2019) concurs with this view. Teachers whose educational approaches are based on modern philosophies of education are not the absolute authorities or sole decision-makers during the teaching and learning process; their principal mission is to play a role as one who guides students in order to establish a proper

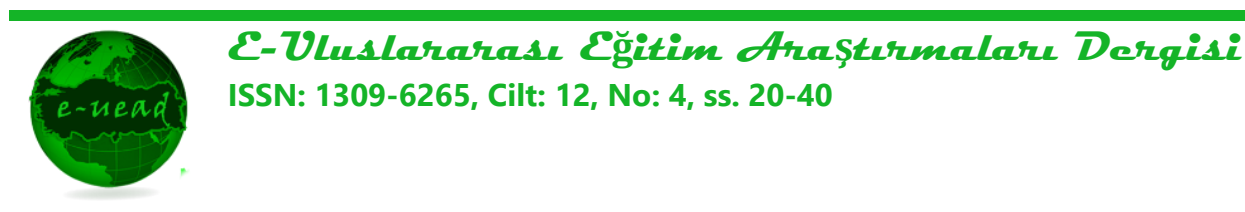


learning environment. Teachers address and pay as much attention as possible to the emotional states and needs of their students (Noddings, 2016; Sönmez, 2008). The present study converges around parallel results with the studies in the literature.

Thus, the results of this study indicate that teachers, to a large degree, adopt learnercentered design and an authoritative classroom management style. In addition, teachers' approaches to curriculum design were found to be a statistically significant predictor of classroom management styles. These results reveal that their approaches to curriculum design play an essential role in adopting a classroom management style that is consistent with constructivist teaching methods.

The following suggestions are included within the scope of the study:

- This study was intended to be carried out in the population of Turkey, but a limited number of participants were reached. A larger sample group can be reached in another study to be conducted. In this way, the generalizability level of the study results is increased. In addition, this study is limited to quantitative data. Another study to be conducted can be designed with mixed method research that includes quantitative and qualitative data together. In this way, more detailed information on the subject can be accessed.

- The results of this study provide important indicators for practitioners. In-service training programs can be designed to show the importance of the relationship between the approaches to curriculum design adopted by teachers and classroom management styles. Within the scope of in-service training, a program in the form of drama can be designed. For example, within the scope of the training program, teachers can be divided into groups. One of the groups creates the teachers who adopt the subjectcentered design approach, while the other groups adopt the learner-centered and problem-centered design approach. Groups present classroom management styles that are appropriate to their design approach. Afterward, they can discuss the relationship between the approaches to curriculum design adopted and classroom management styles and prepare a report as a result evaluation. In other words, a practical in-service training program can be designed with dramatization.

\section{REFERENCES}

Adegbile, J. A., \& Farombi, J. G. (1999). The child-centered curriculum design: Its characteristics and implications for educational practice. Journal of Educational Theory and Practice, 5(1), 57-62.

Aktan, S., \& Sezer, F. (2018). Sınıf yönetimi stilleri ölçeği'nin psikometrik özelliklerinin incelenmesi [Investigating the psychometric characteristics of classroom management styles scale]. Kastamonu Education Journal, 26(2), 439-449. https://doi.org/10.24106/kefdergi.389803

Alcı, B. (2014). Eğitim programı tasarımı ve modeller [Curriculum design and models]. H. Şeker (Ed.), Eğitimde program geliştirme: Kavramlar yaklaşımlar içinde (s. 71-88). Anı Yayıncılık.

Aluçdibi, F., \& Ekici, G. (2012). Ortaöğretim öğrencilerinin biyoloji dersi motivasyon düzeylerine biyoloji öğretmenlerinin sınıf yönetimi profillerinin etkisi [The effect of biology teachers' classroom management profiles on the biology course motivation level of the high school students]. Hacettepe Üniversitesi Eğitim Fakültesi Dergisi, 43, 25-36. 
Arisena, P. P. (2010). An analysıs of classroom management approaches based on the speech acts used by class three teachers in dyatmıka prımary school. PRASi, 6(12), 73-81.

Aslan, S. (2018). Investigating the relation between educational philosophies adopted by prospective teachers and their teaching-learning conceptions. Pegem Eğitim ve Öğretim Dergisi, 8(2), 307-326,

Aydın, A. (2019). Sınıf yönetimi [Classroom management]. Pegem Akademi.

Aytaç, A., \& Uyangör, N. (2020). Öğretmenlerin öğretme-öğrenme anlayışları ile sınıf yönetimi stilleri arasındaki ilişki [The relationship between teachers' teaching-learning conceptions and their classroom management styles]. Akdeniz Eğitim Araştırmaları Dergisi, 14(31), 159-173. https://doi.org/10.29329/mjer.2020.234.8

Barroso, R., \& Dias, D. (2020). Educatıon never goes out of style: Classroom management styles under analysis. Paper presented at 14th International Technology, Education and Development Conference, Valencia, Spain.

Baş, G. (2013). Öğretmenlerin eğitim programı tasarım yaklaşımı tercih ölçeği: Geçerlik ve güvenirlik çalışması [Curriculum design orientations preference scale of teachers: Validity and reliability study]. Educational Sciences: Theory \& Practice, 13(2), 965-992.

Baş, G. (2014). Curriculum design orientation preferences of Turkish teachers. Curriculum and Teaching, 29(2), 61-77. https://doi.org/10.7459/ct/29.2.05

Baş, G. (2015). Öğretmenlerin eğitim felsefesi inançları ile öğretme-öğrenme anlayışları arasındaki ilişki [Correlation between teachers' philosophy of education beliefs and their teaching-learning conceptions]. Eğitim ve Bilim, 182(40), 111-126.

Baş, G., \& Şentürk, C. (2019). Teachers' educational beliefs and curriculum orientations: A relational research. Teachers and Curriculum, 19(1), 45-53. http://dx.doi.org/10.15663/tandc.v19i1.336

Berger, J.-L., \& Girardet, C. (2020). Vocational teachers' classroom management style: the role of motivation to teach and sense of responsibility. European Journal of Teacher Education, 1-17. https://doi.org/10.1080/02619768.2020.1764930

Beyleroğlu, M., Bezci, S., Hazar, M., Tıngaz, E. O., \& Baydar, H. O. (2017). Examination of the classroom management profiles of secondary and primary school teachers. European Scientific Journal, 13(28), 1857- 7431. . http://dx.doi.org/10.19044/esj.2017.v13n28p66

Bosworth, B. (1997). What is your classroom management profile? Teacher talk- a publication for secondary education teachers, 1(2). http://protectiveschools.org/drugstats/tt/v1i2/table.html.

Börekci, C., \& Uyangör, N. (2021). Analyzing pre-service teachers' educational philosophy preferences, curriculum design orientation, and epistemological beliefs with structural equation model. Participatory Educational Research, 8(3), 356-371. https://doi.org/10.17275/per.21.70.8.3

Burul, C. (2018). Öğretmenlerin eğitim programı tasarım yaklaşımı tercihlerinin öğretim programına bağllıklarlyla olan ilişkisinin incelenmesi [Investigation of the relationship between the curriculum design approach preferences of teachers and their curriculum fidelity]. (Yayımlanmamış Yüksek Lisans Tezi). Balıkesir Üniversitesi, Balıkesir.

Büyükkaragöz, S. (1997). Program geliştirme "kaynak metinler" (Geliştirilmiş 2. Baskı). Kuzucular Ofset

Büyüköztürk, Ş. (2007). Sosyal bilimler için veri analizi el kitabı [Manual of data analysis for social sciences]. (8. Baskı). Pegem A Yayıncılık.

Büyüköztürk, Ş., Çakmak, K., E., Akgün, E., Ö., Karadeniz, Ş., \& Demirci, F. (2008). Bilimsel araştırma yöntemleri [Scientific research methods]. Pegem Akademi.

Cheung, D., \& Ng, P-H. (2000). Science teachers' beliefs about curriculum design. Research in Science Education, 30(4), 357-375. http://dx.doi.org/10.1007/BF02461556

Çokluk, Ö., Şekercioğlu, G., \& Büyüköztürk, Ş. (2014) Sosyal bilimler için çok değişkenli istatistik: SPSS ve LISREL uygulamaları [Multivariate statistics for social sciences: SPSS and LISREL applications]. Pegem Akademi. 
Debbağ, M., \& Fidan, M. (2020). Relationships between prospective teachers' multicultural education attitudes and classroom management styles. International Journal of Progressive Education, 16(2), 111-122. https://doi.org/10.29329/ijpe.2020.241.8

Demirel, Ö. (2007). Eğitimde program geliştirme: Kuramdan uygulamaya [Curriculum development: from theory to practice]. (10. Baskı). Pegem A Yayıncılık.

Dewey, J. (2007). Deneyim ve eğitim [Experience and education]. (1. Basım). ODTÜ Yayınclık.

Doğan-Dolapçığlu, S. (2020). Öğretmenlerin program tasarım tercihleri felsefi inançları ve sınıf içi uygulamalarına yönelik karşılaştırmalı bir bakış [A comparative overview of teachers' program design preferences philosophy beliefs and in-class applications]. Elektronik Sosyal Bilimler Dergisi, 19(75), 1108-1121. https://doi.org/10.17755/esosder.643313

Dowden, T. (2017). Curriculum. In D. Pendergast, K. Main, \& N. Bahr (Eds.), Teaching middle years. Rethinking curriculum, pedagogy and assessment (3rd ed., pp. 170-187). Allen \& Unwin.

Dönmez, T. (2015). Illkokul sınıf öğretmenlerinin sınıf yönetimi profilleri ile çocuk haklarına yönelik tutumları arasındaki ilişki [The relationship between classroom managements profiles of primary school teachers and their attitudes towards the children rights]. (Yayımlanmamış Yüksek Lisans Tezi). Gazi Üniversitesi, Ankara.

Ekici, G. (2004). İlköğretim I. kademe öğretmenlerinin sınıf yönetimi profillerinin değerlendirilmesi [Assessment of teachers' Classroom Management Profiles in First-Level Elementary Education]. Eğitim ve Bilim, 29(131), 50-60.

Ekici, G., Aluçdibi, F., \& Öztürk, N. (2012). Biyoloji öğretmenlerinin sınıf yönetimi profillerini cinsiyet ve kıdem değişkenleri açısından incelenmesi [Investigation of biology teachers' classroom management profiles in terms of gender and seniority variables]. Dicle Üniversitesi Sosyal Bilimler Enstitüsü Dergisi, 4(8), 13-30.

Ellis, A. K. (2015). Eğitim programı modelleri [Curriculum models]. (Çev. Ed: A. Arı). (1. Baskı). Eğitim Yayınevi.

Emes, C., \& Cleveland-Innes, M. (2003). A journey toward learner-centered curriculum. Canadian Journal of Higher Education, 33(3), 47-69. https://eric.ed.gov/?id=EJ788477

Eren, A., \& Çetin, G. (2019). Pre-service teachers' beliefs about the teaching profession, curriculum orientations, and personal responsibility. Curriculum Perspectives, 39, 19-32. https://doi.org/10.1007/s41297-018-00061-1

Evertson, C. M., \& Weinstein, C. S. (2006). Classroom management as a field of inquiry. In C. M. Evertson \& C. S. Weinstein (Eds.), Handbook of classroom management: Research, practice, and contemporary issues (pp. 3-16). Lawrence Erlbaum Associates.

Fidan, N. (2012). Okulda öğrenme ve öğretme [Learning and teaching at school]. Pegem A Yayıncılık.

Field, A. (2005). Discovering statistics using SPSS. Sage Publication

Gutek, L. G. (2006). Eğitime felsefi ve ideolojik yaklaşımlar [Philosophical and ideological approaches to education]. (Çev: N. Kale). (3. Basım). Ütopya Yayınevi.

Jenkins, S. H. (2009) Measuring teacher beliefs about curriculum orientations using the modifiedcurriculum orientations inventory, The Curriculum Journal, 20(2), 103-120, https://doi.org/10.1080/09585170902948798

Karaman, P., \& Bakaç, E. (2018). Öğretmenlerin eğitim programı yaklaşımı tercihlerinin çeşitli değişkenler açısından incelenmesi [investigating the teachers' curriculum orientations in terms of various variables]. Abant İzet Baysal Üniversitesi Eğitim Fakültesi Dergisi, 18(1), 304-320. https://doi.org/10.17240/aibuefd.2018..-364651

Karasar, N. (2006). Bilimsel araştırma yöntemi [Scientific research method]. (16. Baskı). Nobel Yayın Dağıtım. 
Kozikoğlu, İ., \& Uygun, N. (2018). Öğretmenlerin benimsedikleri eğitim felsefeleri ile eğitim programı tasarım yaklaşımları arasındaki ilişkinin incelenmesi [Investigation of the relationship between teachers' philosophies of education beliefs and curriculum design approaches]. Çukurova Üniversitesi Eğitim Fakültesi Dergisi, 47(2) ,411-438. https://doi.org/10.14812/cuefd.404297

Korkmaz, İ. (2017). Eğitim programı: Tasarımı ve geliştirilmesi [Curriculum: Design and development]. A. Doğanay (Ed.), Öğretim ilke ve yöntemleri içinde (s. 3-38). Pegem A Yayıncılık.

McGinty, J. P. (2000). Classroom management styles and their link to discipline infractions. (Unpublished Master Thesis). Rowan Universiy, New Jersey.

Moore, K. D. (1989). Classroom teaching skills: a primer. Random House Inc.

Noddings, N. (2016). Eğitim felsefesi [Educational philosophy]. (Çev: R. Çelik). Nobel Akademik Yayıncılık.

Oliva, P. F. (1997). Developing the curriculum. Longman.

Ornstein, A., C., \& Hunkins, P. F. (2014). Programın felsefi temelleri [Philosophical foundations of the curriculum]. (Çev. S. Demiral). Eğitim programı: Temeller, ilkeler ve sorunlar içinde (s. 43-84). (Çev. Editörü Arı, A.). Eğitim Yayınevi.

Özden, Y. (2014). Öğrenme ve öğretme [Learning and teaching] (12. Baskı). PegemA Yayıncılık.

Pehlivan, M., \& Şahin-Taşkın, Ç. (2020). Sınıf öğretmenlerinin eğitim programı tasarım yaklaşımı tercihleri ve düşünme becerilerinin öğretimine yönelik sınıf içindeki uygulamaları arasındaki ilişki [The relation between classroom teachers' curriculum design orientations preferences and classroom practices for teaching thinking skills]. Milli Eğitim, 49(225), 89-127.

Print, M. (1993). Curriculum development and design. National library of Australia cataloging in-publication entry.

Sadık, S., \& Sadık, F. (2013). Investigating classroom management profiles of pre-service teachers (Cukurova University sample). Procedia - Social and Behavioral Sciences, 116, 2369 - 2374. . http://dx.doi.org/10.1016/j.sbspro.2014.01.575

Saylan, N. (1995). Eğitimde program tasarısı: Temeller-prensipler-kriterler [Curriculum design: Foundationsprinciples-criteria]. İnce Ofset.

Scrivener, J. (2012). Classroom management techniques. Cambridge University Press.

Sezer, F., Aktan, S., Tezci, E., \& Erdener, M. A. (2017). Öğretmenlerin yaşam stilleri ve sınıf yönetim profillerinin bazı değişkenler açısından incelenmesi [The ınvestıgatıng of teachers' lıfe styles and classroom management profiles in terms of some varıables]. Turkish Studies, 12 (33), 167-184. http://dx.doi.org/10.7827/TurkishStudies. 12680

Sönmez, V. (2001). Program geliştirmede öğretmen el kitabı [Teacher's handbook in curriculum development]. Anı Yayıncılık.

Sönmez, V. (2008). Eğitim felsefesi [Education philosophy] (8. Baskı). Anı Yayıncılık

Şahin, Ü. (2020). Curriculum design approaches of pre-service teachers receiving pedagogical formation training. International Journal of Progressive Education, 16(4), 192-203. http://dx.doi.org/10.29329/ijpe.2020.268.12

Talşık, E. (2015). İnvestigating classroom management profiles of in-service music teachers in Turkey. Journal of Education and Sociology, 6(1). http://dx.doi.org/10.7813/jes.2015/6-1/97

Tanner, D., \& Tanner, L. (1995). Curriculum development: Theory into practice. Prentice-Hall.

Tanrıverdi, B., \& Apak, Ö. (2013). Pre-service teachers' beliefs about curriculum orientations. Procedia Social and Behavioral Sciences, 116, 842 - 848. http://dx.doi.org/10.1016/j.sbspro.2014.01.308

Tekbıyık, A. (2014). Iliş̧kisel araştırma yöntemi [Relational research method]. M. Metin (Ed.). Kuramdan uygulamaya eğitimde bilimsel araştırma yöntemleri içinde (s. 99-114). Pegem Akademi.

Tekin, H. (2002). Eğitimde ölçme ve değerlendirme. Yargı Yayıncılık.

Toprakçı, E. (2002). Sınıf Örgütünün Yönetimi. Ütopya Yayınları 
Toprakçı, E. (2012) Rethinking classroom management: A new perspective, a new horizon. E-International Journal of Educational Research, 3(3), 84-110. https://files.eric.ed.gov/fulltext/ED538969.pdf

Toprakçı, E. (2017). Sınıf Yönetimi. Pegem Akademi Yayınları

Tucker, T. (2011). What they want and how they want it: Students expectations of ESL curriculum at the classroom level. Journal of College Teaching \& Learning, 8(11), 11-19.

Turan, S. (2019). Sınıf yönetiminin temelleri [Basics of classroom management]. M. Şişman ve S. Turan (Ed.). Sınıf yönetimi içinde (ss. 1-20). Pegem Akademi.

Tyler, R. W. (2014). Eğitim programlarının ve ögretimin temel ilkeleri [Basic principles of curriculum and teaching]. (Çev. M. E. Rüzgar ve B. Aslan). Pegem A Yayıncılık.

Ünsal, S., \& Korkmaz, F. (2017). Eğitim programı tasarımı tercihlerine yönelik öğretmen görüşleri [Teachers' views on their preferences regarding curriculum design orientation]. Mersin Üniversitesi Eğitim Fakültesi Dergisi, 13(1), 275-289. http://dx.doi.org/10.17860/mersinefd.305977

Varış, F. (1978). Eğitimde program geliştirme: Teori ve teknikler [Curriculum development in education: Theory and techniques] (3. Baskı). Ankara Üniversitesi Eğitim Fakültesi Yayınları.

Yazıcıoğlu, Y., \& Erdoğan, S. (2004). SPSS uygulamalı bilimsel araştırma yöntemleri [SPSS applied scientific research methods]. Detay Yayınculı.

Yılmaz, K. (2009). Primary school teachers' views about pupil control ideologies and classroom management styles. Cypriot Journal of Educational Sciences 4(3), 157-167.

Yılmaz, K. (2011). İlköğretim okulu öğretmenlerinin sınıf yönetimi tarzları ile demokratik değerlere ilişkin görüşleri arasındaki ilişki. Değerler Eğitimi Dergisi, 9(21), 147-170. 


\section{Öğretmenlerin Eğitim Programı Tasarum Yaklaşumı Tercihleri ve Sunıf Yönetimi Stilleri Üzerine ilişkisel Bir inceleme}

\author{
Dr. Alper Aytaç (Öğretmen) \\ Milli Eğitim Bakanlığı-Türkiye \\ ORCID: 0000-0002-5087-8482 \\ alperaytac10@gmail.com
}

\author{
Necip Kaygısız (Öğretmen) \\ Milli Eğitim Bakanlığı-Türkiye \\ ORCID: 0000-0002-5614-7269 \\ necipbey.org@gmail.com
}

\begin{abstract}
Özet
Bu araştırmada öğretmenlerin eğitim programı tasarım yaklaşımı tercihleri ile sınıf yönetimi stilleri arasındaki ilişkinin incelenmesi amaçlanmıştır. ilişkisel tarama modeli ile tasarlanan araştırmanın örneklemini, 20202021 eğitim-öğretim yılında 334 öğretmen oluşturmuştur. Örneklem seçiminde uygun örnekleme yöntemi kullanılmıştır. Araştırmada veri toplama aracı olarak Eğitim Programı Tasarım Yaklaşımı Tercih Ölçeği ve Sınıf Yönetimi Stilleri Ölçeği kullanılmıştır. Verilerin analizinde betimsel istatistik (aritmetik ortalama, standart sapma), Pearson korelasyon analizi, çoklu doğrusal regresyon analizi kullanılmıştır. Araştırmanın ilk sorusunun sonuçlarına göre öğretmenlerin ağırlıklı olarak öğrenen merkezli tasarımları ve yetkeci sınıf yönetimi stillerini tercih ettikleri saptanmıştır. Araştırmanın ikinci sorusuna göre öğretmenlerin eğitim programı tasarım yaklaşımı tercihleri ile sınıf yönetimi stilleri arasında anlamlı ilişkiler saptanmıştır. Araştırmanın üçüncü sorusuna göre ise ögrretmenlerin eğitim programı tasarım yaklaşımı tercihlerinin sınıf yönetimi stillerini anlamlı şekilde yordadığı saptanmıştır. Buna göre eğitim programı tasarım yaklaşımı tercihleri; otoriter sınıf yönetimi stilleri alt boyutundaki değişimin yaklaşık \% 17'sini, ilgisiz sınıf yönetimi stilleri alt boyutundaki değişimin yaklaşık \% 5'ini, yetkeci sınıf yönetimi stilleri alt boyutundaki değişimin yaklaşık \% 25'ini, serbest sınıf yönetimi stilleri alt boyutundaki değişimin yaklaşık \% 9'unu açıklamaktadır. Bu bakımdan eğitim programı tasarım yaklaşımlarının öğrenme-öğretme süreci açısından önemine ilişkin öğretmenlere yönelik hizmet-içi eğitim uygulamaları düzenlenebilir. Ayrıca yapılacak olan başka bir çalışmada daha büyük bir örneklem kitlesi ile karma yöntem kullanılarak daha detaylı sonuçlara ulaşılabilir.
\end{abstract}

Anahtar Kelimeler: Eğitim programı, Eğitim programı tasarım yaklaşımları, Sınıf yönetimi, Sınıf yönetimi stilleri, Öğretmenler.

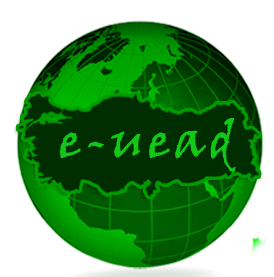

E-Uluslararası Eğitim Araşturmalart Dergisi

Cilt: 12, No: 4 , ss. $20-40$

Araşturma Makalesi

Gönderim: 26-04-2021 Kabul: $30-09-2021$

\section{Önerilen Atıf}

Aytaç, A. ve Kaygısız, N. (2021). Öğretmenlerin eğitim programi tasarim yaklaşimi tercihleri ve sinif yönetimi stilleri üzerine ilişkisel bir inceleme, E-Uluslararası Eğitim Araştırmaları Dergisi, 12(4), 20-40. DOI: https://doi.org/10.19160/e-ijer.928384

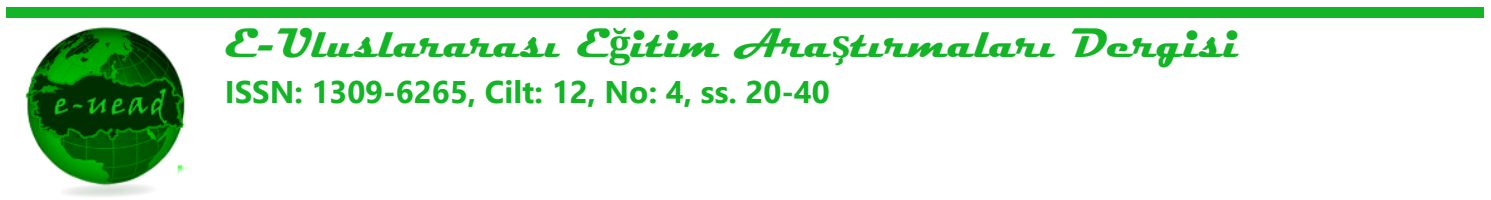




\section{Genişletilmiş Özet}

Problem: Eğitim programı, planlı ögrenme-öğretme faaliyetlerini ifade etmektedir (Demirel, 2007). Eğitim programı tasarımını ise, bir programın hangi unsurlardan oluşması gerektiğini, bu unsurların nasıl sıralanıp düzenleneceğini ortaya koyan bir plan olarak belirtmek mümkündür (Saylan, 1995). Bir öğretmenin tercih ettiği eğitim program tasarımı yaklaşımının öğrenme-öğretme süreci açısından önemli olduğunu söylemek mümkündür (Baş, 2014). Nitekim alanyazında yapılan araştırmalarda (Baş ve Şentürk, 2019; Kozikoğlu ve Uygun, 2018) öğretmenlerin benimsedikleri eğitim felsefesi eğilimleri ile tercih ettikleri eğitim programı tasarım yaklaşımları arasında anlamlı ilişkiler saptanmıştır. Bu kapsamda öğretmenlerin eğitim felsefesi eğilimlerinin program tasarısı yaklaşımlarında bir etkiye sahip olduğu anlaşılmaktadır. Sınıf yönetimini sını örgütünün yönetimi açısından değerlendiren görüşün yanı sıra, genellikle dersin yönetimi ya da öğretimin yönetimi olarak görüldügü söylenebilir (Toprakçı, 2002; Toprakçı, 2012; Toprakçı, 2017). Bu ikinci anlamı temelinde sınıf yönetimi, öğretmenlerin öğrenme-öğretme ortamında öğrenci faaliyetlerini kontrol ve organize etmesini ifade etmektedir (Scrivener, 2012). Bir öğretmenin sınıf yönetimini sağlarken benimsemiş olduğu yöntemlere ise sınıf yönetimi stili adıverilebilir (Bosworth, 1997). Öğretmenlerin sahip oldukları sınıf yönetimi stillerinin öğrenme-öğretme süreci açısından önemli olduğunu söylemek mümkündür (Ekici, 2004). Nitekim ilgili alanyazında yapılan bir araştırmada (Aytaç ve Uyangör, 2020) ögrretmenlerin sınıf yönetimi stilleri ile ögrretim anlayışları arasında bir ilişki saptanmış̧tır. Baş'ın (2015) araştırmasında da öğretmenlerin öğretim anlayışlarının eğitim felsefesi eğilimlerden etkilendiği tespit edilmiştir. Bu bağlamda hem sınıf yönetimi stilleri hem de eğitim programı tasarım yaklaşımlarının eğitim felsefesi eğilimlerinden etkilendikleri anlaşılmaktadır. Bu bakımdan bu araştırmalar bütünsel olarak göz önüne alındı̆ında, öğrenme-öğretme süreci açısından önemli olduğu anlaşılan bu iki değişkenin birbiri ile ilişkili olabileceği düşünülmüş ve bu yönde bir araştırma tasarlanmıştır. ilgili alanyazında bu iki değişken arasındaki ilişkiyi inceleyen bir çalışmaya rastlanmamıştır. Bu bakımdan, bu iki değişken arasındaki ilişkisinin incelenmesinin ilgili alanyazında çalışmalar yapan araştırmacılara çeşitli perspektifler sunabileceği düşünülmektedir.

Yöntem: Bu araştırmada öğretmenlerin tercih ettikleri eğitim programı tasarım yaklaşımları ile sınıf yönetimi stilleri arasındaki ilişkiyi incelemek amaçlandığı için ilişkisel tarama modeli tercih edilmiştir. Araştırmanın örneklemini 2020-2021 eğiitm-öğretim yılında görev yapmakta olan ve araştırmaya gönüllü olarak katılım göstermiş olan 334 ögretmen oluşturmuştur. Örneklem seçiminde uygun örnekleme yöntemi tercih edilmiştir. Araştırmada Baş (2013) tarafından geliştirilen "Eğitim Programı Tasarım Yaklaşımı Tercih Ölçeğı" (EPYTÖ) ve Bosworth (1997) tarafından geliştirilen ve Aktan ve Sezer (2018) tarafından Türkçe'ye uyarlanan "Sınıf Yöntemi Stilleri Ölçeği" (SYSÖ) kullanılmıştır. EPYTÖ üç boyuttan ve 30 maddeden oluşmaktadır. SYSÖ dört boyuttan ve 12 maddeden oluşmaktadır. Verilerin analiz edilmesi aşamasında öncelikle uç değerler kontrol edilmiş ve Mahalonobis uzaklıkları incelenmiştir. Basıklık ve çarpıklık değerlerinin kabul edilebilir aralıklarda olduğu tespit edilmiş ve verilerin normal dağılım gösterdiği varsayılmıştır. Bu doğrultuda verilerin analizinde betimsel istatistik (aritmetik ortalama ve standart sapma), Pearson korelasyon analizi ve çoklu doğrusal regresyon analizi tercih edilmiştir.

Sonuçlar: Araştırmanın ilk sonucuna göre konu merkezli tasarım (KMT) alt boyutunun orta düzeyde, ögrenen merkezli tasarım (ÖMT) alt boyutunun ve sorun merkezli tasarım (SMT) alt boyutunun çok yüksek düzeyde olduğu tespit edilmiştir. Araştırmanın ikinci sonucuna göre öğretmenlerin eğitim programı tasarım yaklaşımı tercihleri ile sınıf yönetimi stilleri arasında anlamlı ilişkiler elde edilmiştir. Araştırmanın üçüncü sonucuna göre ise öğretmenlerin eğitim programı tasarım

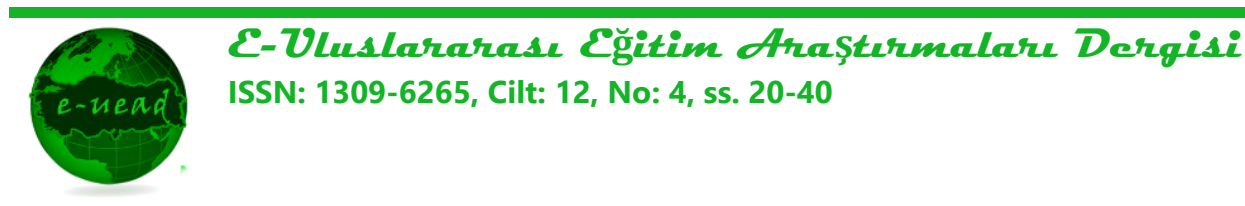


yaklaşımlarının sınıf yönetimi stillerini anlamlı şekilde yordadığı saptanmıştır. Buna göre konu merkezli tasarım (KMT) alt boyutu; otoriter sınıf yönetimi stili (OSYS) alt boyutunu ve ilgisiz sınıf yönetimi stili (ISYS) alt boyutunu pozitif yönde yordarken, yetkeci sınıf yönetimi stili (YSYS) alt boyutunu negatif yönde anlamlı şekilde yordamaktadır. Öğrenen merkezli tasarım (ÖMT) alt boyutu; otoriter sınıf yönetimi stili (OSYS) alt boyutunu negatif yönde yordarken, yetkeci sınıf yönetimi stili (YSYS) alt boyutunu ve serbest sınıf yönetimi stili (SSYS) alt boyutunu pozitif yönde anlamlı şekilde yordamaktadır. Sorun merkezli tasarım (SMT) alt boyutu; ilgisiz sınıf yönetimi stili (ISYS) alt boyutunu negatif yönde yordarken, yetkeci sınıf yönetimi stili (YSYS) alt boyutunu pozitif yönde yordamaktadır.

Öneriler: Bu araştırma, Türkiye evreninde gerçekleştirilmek istenmiş, ama sınırlı sayıda katılımcıya ulaşılmıştır. Yapılacak olan başka bir çalışmada daha büyük örneklem grubuna ulaşılabilir. Bu sayede araştırma sonuçlarının genellenebilirlik düzeyi arttırılmış olur. Ayrıca bu araştırma nicel veriler ile sınırlıdır. Yapılacak olan başka bir çalışma, nicel ve nitel verilerin birlikte yer aldığı karma yöntem araştırması ile tasarlanabilir. Bu sayede konu ile ilgili daha detaylı bilgilere ulaşılabilir. Ikinci olarak, bu araştırma sonuçları uygulayıcılar için önemli göstergeler sunmaktadır. Öğretmenlerin benimsedikleri eğitim programı tasarım yaklaşımları ile sınıf yönetimi stilleri arasındaki ilişkinin önemini uygulamalı olarak gösteren hizmet-içi eğitim programları tasarlanabilir. Hizmet-içi eğitim kapsamında drama şeklinde bir program tasarlanabilir. 